\begin{tabular}{|l|l|l||}
\hline \multicolumn{2}{|c|}{ PublisherInfo } \\
\hline \hline PublisherName & $:$ & BioMed Central \\
\hline \hline PublisherLocation & $:$ & London \\
\hline \hline PublisherImprintName & $:$ & BioMed Central \\
\hline \hline
\end{tabular}

\title{
GASPing for genes
}

\begin{tabular}{|l|l|l||}
\hline \multicolumn{2}{|c||}{ ArticleInfo } \\
\hline \hline ArticleID & $:$ & 3676 \\
\hline \hline ArticleDOI & $:$ & $10.1186 /$ gb-spotlight-20000504-02 \\
\hline \hline ArticleCitationID & $:$ & spotlight-20000504-02 \\
\hline \hline ArticleSequenceNumber & $:$ & 113 \\
\hline \hline ArticleCategory & $:$ & Research news \\
\hline ArticleFirstPage & $:$ & 1 \\
\hline \hline ArticleLastPage & $:$ & 2 \\
\hline \hline & $:$ & RegistrationDate : 2000-05-04 \\
ArticleHistory & $:$ & OnlineDate $: 2000-05-04$ \\
\hline \hline ArticleCopyright & $:$ & BioMed Central Ltd2000 \\
\hline \hline ArticleGrants & $:$ & \\
\hline \hline ArticleContext & $:$ & 130591111 \\
\hline \hline
\end{tabular}




\section{William Wells}

Email: wells@biotext.com

In the Genome Annotation Assessment Project (GASP), 12 groups tested their ability to identify genes in 3 million base pairs of Drosophila DNA. The results are reported in eight papers in the April issue of Genome Research. The majority of the groups correctly identified over $95 \%$ of the coding nucleotides. Less successful were predictions of intron/exon boundaries, which were correct for just over $40 \%$ of the genes, and predictions of promoter locations, which suffered from a high rate of false positives.

\section{References}

1. Genome Research Homepage, [http://www.genome.org/]

This PDF file was created after publication. 